\title{
IŞYERINDE CINSEL TACiZ: ERZURUM ILINDE BANKACILIK SEKTÖRÜ ÜZERINE BIR UYGULAMA
}

\author{
Dr. G. Mine Gerni \\ Emekli Örretim Üyesi
}

\section{Özet}

Bu çalışmada işyerinde cinsel taciz konusu çeşitli yönleriyle incelenmiş ve Türkiye'de kadın istihdamınun en yoğun olduğu alanlardan biri olan bankacllk sektöründe yerel düzeyde bir uygulama yapılmuştr. Erzurum ilindeki ticari bankalarda görev yapan kadınların cinsel tacizle karşılaşma durumlan ve cinsel taciz konusundaki tutumları araşturılmuştır. Elde edilen bulgular, ildeki kadın banka personelinin cinsel taciz karşısında durumunun dünyadaki hemcinslerinden farkluluk göstermediğini ortaya koymaktadır. Çalışmada cinsel tacizi önlemeye yönelik kurum politikalanının gerekliliği vurgulanmuş ve bazı öneriler sunulmuştur.

Sexual Harassment in the Workplace: An Empirical Study in the Banking Sector in the City of Erzurum

\section{Abstract}

In this article the theoretical framework of sexual harassment in the workplace is briefly reviewed, and the findings of an empirical study which is done on the local level in the banking sector where women's employment is relatively concentrated are summarized. The actions of, and reactions against, harassment are investigated in the commercial banks in the city of Erzurum. The findings show that the women working in the banks live and work under the same circumstances as their co-workers in the world with respect to sexual harassment. The article also stresses the necessity of organizational policies aimed at preventing sexual harassment and, in this context, some suggestions are presented. 


\section{İşyerinde Cinsel Taciz: Erzurum İlinde Bankacilık Sektörü Üzerine Bir Uygulama}

\section{Giriş}

Işyerinde cinsel taciz konusu, toplumsal, psikolojik ve ekonomik olmak üzere birçok boyuta sahip bir olgudur. Işyerinde cinsel taciz sorunu toplumların gündemine son yıllarda girmiş bulunmaktadır. Endüstriyel devrimden itibaren çalışma ilişkilerinde sürekli var olan bir sorun olmasına rağmen, iş yerinde cinsel taciz konusunun ele alınması 1970'li yilların ortalarına rastlar. Is hayatında cinsel taciz konusuna duyarlılı̆ın oluşması ve tacizi önlemeye yönelik yasal düzenlemelerin gerçekleşmesinde, kadınların iş dünyasında zamanla sayılarının artmasının ve özellikle 1960'larda başlayan kadın kuruluşlarının çabalarının payı büyüktür. Ülkemizde de son yllarda kadın kuruluşları ve medyanin gayretleriyle konuya ilgi artmakla beraber, cinsel tacizi doğrudan ele alan araştırmalar henüz mevcut değildir. Bu konuda yeni yapilan kapsamlı bir çalışma (BAKIRCI, 2000) daha çok konuyu hukuki boyutuyla ele almaktadır.

Cinsel taciz üzerine yaplan ilk araşturmalar, cinsel tacizin tanumı ve kadınların işyerinde bu gibi davranışlarla ne ölçüde karşılaştıkları üzerine yoğunlaşmıştır (GUTEK, 1993). ABD'de yapılan hukuki tanumlardan birisi şöyledir: Cinsel taciz, eşit olmayan güç ilişkisi şartlarında cinsel ihtiyaçların karşı tarafça istenmeyen talepleridir (MACKINNON, 1979: 1). Diğer bir tanıma göre cinsel taciz, mevcut is kazancı için hiçbir faydası olmamasına yada işin kaybedilme tehlikesine rağmen sürekli ve istenmeyen cinsel davranışların sergilendiği düşmanca bir iş ortamını ifade eder (CLEVELAND, 1994: 170). Cinsel tacizi Türk Ceza Hukuku açısından inceleyen Artuk'a göre ise cinsel taciz, birey ve bireylerin edep ve iffetlerine yönelmiş rahatsız edici nitelikteki hareketlerdir (BAKIRCI, 2000: 91).

Cinsel taciz kavramsal, deneysel ve hukuksal olarak belirlenmiş olsa da , cinsel tacizi oluşturan davranışarın neler olduğu ile ilgili tartşmalar devam etmektedir. Bu konuda bir fikir birliğinin oluşamamasının temel nedeni, cinsel 
tacizin algılanışındaki cinsiyet farklılıklardır. Cinsel tacizin algılanışı, davranışın şiddeti ile tacizcinin ve hedefin özelliklerine bağlıdır (CLEVELAND, 1994).

Sosyal ve psikolojik nedenlerle çoğu kez mağdurların ortaya çıkmaması cinsel tacizin gerçek boyutlarını belirlemeyi zorlaştırmaktadır. Cinsel taciz konusunda ilk ve en önemli adımları atan ABD'de yaplan tahminler, işyerinde cinsel tacize uğrayan kadınların oranını $\% 42$ ile \%90 arasında değiştiğini göstermektedir (FITZGERALD vd., 1988; USMSPB, 1981). Cinsel tacize uğrayanlann ancak \%5'inden daha azı durumu resmi şikayet konusu yapabilmişlerdir (FITZGERALD / SHULLMAN, 1993).

Türkiye'de ise işyerinde cinsel tacizle ilgili doğrudan ve kapsaml çalışmalar henüz yapılmamış olduğundan, cinsel tacizin geçmişini ve boyutların ortaya koymak kolay değildir. Ülkemizde geçerli toplumsal değerler sistemi taciz mağduru kadınun daha fazla mağdur olacağı korkusuyla konuşmasını engellemektedir. Buna rağmen doğrudan cinsel tacizle ilgili olmayan fakat cinsel tacizle ilgili soruların da sorulduğu cinsiyet ayrımcılığın araştıran çalı̧̧malardan, işyerinde cinsel tacizin Türkiye'de de önemli bir sorun olduğu anlaşılmaktadır. Bu çalışmalardan biri, Nazmiye Yeni'ye ait Ankara ve Denizli illerinde 12-19 yaş gruplarındaki konfeksiyon işçilerini kapsayan araştırmadır (TÜBA, 1993). Araştırmada anılan iş̧̧lerin \%12'si cinsel tacize uğradıklarını ifade etmişlerdir. Diğer bir çalışma Hak-Iş'e bağlı Öz-iplik Iş Sendikası tarafından yapılan tekstil sektöründe kadın işgücünün istismarı konulu araştırmadır. Araştırmaya katılan kadın çalışanların \%11'i tacizle karşılaştıklarını ifade etmişlerdir (KORAY vd., 1999).

Ayrıca Başbakanlık Kadının Statüsü ve Sorunları Genel Müdürlüğü'nün "Kadın Istihdamının Geliştirilmesi Projesi" adı altında kadınlara karşı cinsiyet ayrımcilığın inceleyen dört ayrı araştırmada da cinsel tacize ilişkin sorunlar yer almıştır. Adı geçen bu araştırmalar hastane (ELHAN vd., 2000), büro ve mağaza (TEMPO ARAŞTIRMA, 1996) ve banka çalışanları (EYÜBOĞLU vd., 2000) ile İş ve Iş̧̧i Bulma Kurumu'nun işgücü yetiştirme kursların bitiren bilgisayar destekli işler, turizm/otelcilik ve tekstil/konfeksiyon işlerine yerleştirilenler (AKHUN vd., 1996) arasında yapılmıştır. Bu araştırmalarda adı geçen alanlarda çalışanların cinsel tacize uğradıkları örnek olaylarla saptanmış ancak cinsel tacizin hangi oranlarda ortaya çıktığı belirtilmemiştir. Özellikle hastanelerde taciz olaylarının sıkça yaşandığı sonucuna varılmıştır. Hastanelerle ilgili araştrmanın diğer bir sonucu kadın doktorlardan ziyade, hemşirelerin ve sekreterlerin daha fazla tacize uğradıklaridır (ELHAN vd., 2000). Bu sonuç kadın doktorlara göre hemşire ve sekreterlerin daha güçsüz konumda olmaları ve toplumun hemşire ve sekreterlerin bu işlere müsait oldukları yolundaki önyargıları ile açıklanabilir.

Bu çalışmada ise işyerinde cinsel taciz konusu mağdurlar, tacizci, sosyal 
çevre ve kurum açısından irdelenmiş ve Erzurum ilinde bankacilık sektöründeki kadın çalışanlar üzeride bir uygulama yapılmıştır.

\section{Cinsel Taciz Olgusu}

\section{Taciz Mağdurları}

Issyerlerinde genellikle taciz edenler erkekler iken, cinsel tacize hedef olanlar daha çok kadınlardır (RYAN / KENIG, 1991). Cinsel tacize uğrayan kadın ve erkek oranlarında ülkelerarası farklar olmakla birlikte ortak sonuç daha çok kadınların taciz edildikleri şeklindedir. Erkek çalışanların \%15'i cinsel tacize maruz kalırken, kadınlarda bu oranın \%42 olduğu kaydedilmiştir (STEPHENSON vd., 1989). Araştırmalar ne tacize uğrayan kadınların ne de tacizde bulunan erkeklerin belirli bir tipi oluşturmadığını göstermektedir. Kadının ırkı, etnik kökeni, yaşı, mesleği, sosyo-ekonomik seviyesi ve fiziksel görüntüsü tacize uğraması konusunda belirleyici değildir (PALUDI vd., aktaran BAKIRCI, 2000). Ancak içinde bulunulan belirli durumlar tacizi daha kolay hale getirmektedir. Örneğin dul, boşanmıs veya yalnız yaşayan kadınlar, ekonomik güçlük çeken ve iş yaşamında deneyimsiz kadınlar, düşük ücretli, düşük eğitimli ve devamlılık arzetmeyen işlerdeki kadınlar, erkeklerin sayıca daha yoğun olduğu işyerlerindeki ve geleneksel erkek işi kabul edilen işlerde çalışan kadınlar daha fazla tacize hedef olmaktadirlar (FAIN / ANDERTON, 1987; GUTEK / DUNWOODY, 1987).

Taciz eyleminde bulunan erkekler genellikle hedeflerine göre daha üst statüde daha yaşlı ve evli kimselerdir. Taciz edenlerin evli olmaları yönündeki bulgu, tacizin romantik bir ilgi değil daha çok pragmatik amaca hizmet eden bir eylem olduğunu ortaya koymaktadır (FITZGERALD / WERTZMAN, 1990).

Gutek işyerlerinde kadın cinselliğinin erkeklere kuyasla daha fazla algılandığını ve kadın cinselliğinin ön plana çıkmasının taciz olaylarını artırdığın iddia etmektedir. Oysa işyerlerinde erkeklerin cinsellikleri çok öne çıkmamaktadır. Erkekler için doğal kabul edilen rekabetçilik, iddiacalık, güce yönelik olma gibi özellikler cinsellik taşıyan ifade ve şakalarla ortaya konsa da dikkat çekmemektedir (GUTEK, 1989).

Cinsel taciz kadınlar üzerinde erkeklerin gụ̧̈ ilişkisini ortaya koyar. Cinsel taciz bir bakıma cinsel zevk elde etmek uğruna gücün yanlı̧ kullanılmasıdır. Bu durum kadının toplum içindeki ikincil konumuna uygun şekilde işyerinde cinsel rolüne dikkat çekilerek onun zayif pozisyonunda devamını sağlayan bir süreçtir. Cinsel tacizin amacı, kadının işteki rolünü ve fonksiyonların geri plana itip onun toplumdaki asıl fonksiyonunun cinselliği olduğunu vurgulamak ve kadının cinsiyete dayalı çaresizliği, yetersizliği ve pasifliğine dikkat çekilerek çalışma rolünü azaltmaktır. Cleveland ve Kerst 
(1993) kurumsal, kişisel veya kişiler arası güç özelliklerinin cinsel tacizle olan bağlantıların ortaya koymuşlardır. Sosyal ve kurumsal güç kaynakları cinsel tacizi artırabilen ya da engelleyebilen çalışma şartlarına temel oluştururlar. Erkekler işyerlerinde formal ve informal açıdan kadınlardan daha güçlü konumdadırlar. Cinsel taciz, güçlünün güçsüz üzerinde kontrol sağlama metodlarindan birisidir (MORRISON / VON GLINOW, 1990). Cinsel tacizde formal güç farklılıkları taciz eden üst olduğu zaman daha açık gözükmektedir. Cinsel taciz üst tarafından yapılırsa, üstün işgal ettiği pozisyon nedeniyle tacizin sonuçları hem mağdur hem de kurum için daha zararlıdır. Cleveland ve Kerst (1993) ayn ya da benzer konumlarda bulunan kadın ve erkekler arasındaki informal güç farklarınun da taciz ortamı yaratabildiğini göstermişlerdir. İsyerlerinde başarı ve destek sağlayan, terfi ve kabul görme kararlarında etkili olan sosyal iletişim ağlarına kadınlar fazla katılamamaktadırlar. Bu ilişki ağlarına dahil olmak erkek çalışana resmi statüsü dışında bir güç kazandırmaktadır. Işte aynı statüdekiler veya astlar tarafından gerçekleştirilen cinsel taciz, kadının sahip olmadığı informal güç kaynaklarına erkeğin sahip olduğu durumlarda ortaya çıkabilir.

Kadınlar işyerlerinde seyrek rastlanmakla beraber diğer kadınların tacizine de uğrayabilmektedirler. ABD Liyakat Sistemini Koruma Kurulu'nun 1994 'de yaptı̆̆ı araştırmada araştırmaya katılan kadınların \% 1'i diğer kadınların tacizine uğradıkların belirtmişlerdir (USMSPB, 1994). Cinsel tacize hedef olanlar daha çok kadınlar olmasına karşılık erkeklerin de kadınlar tarafından tacize uğrayabildiği durumlar vardır. Ancak güçlü toplumsal cinsiyet rolleri ve örgütlerdeki cinsiyetçi yapılanma gibi nedenlerle erkekler cinsel tacizden kadınlar kadar kötü etkilenmemektedirler. Erkeklere yapılan tacizin farklı bir yönünü ortaya çıkaran bir araştırma, erkeği taciz eden kadınların hedeflerinden daha genç, bekar benzer ya da daha alt konumda olan kişiler olduklarını ortaya koymaktadırlar (GUTEK / DUNWOODY, 1989). Böylece tacize hedef olan erkekler işlerini kaybetme ve kariyerlerinde engellenme gibi durumlarla nadiren karşılaşmaktadırlar.

\section{Taciz Mağduru Açısından Sonuçları}

Cinsel taciz sadece mağduru değil, ayn zamanda kurumun etkinliğini, tacizciyi ve diğer çalışanları da etkilemektedir. Ancak tacizin, taciz mağduru kadınlar üzerindeki etkileri çok yönlü ve önemlidir. Cinsel taciz mağdurunun işiyle, özel ve sosyal hayatyyla ilgili önemli sorunlar yaşamasına neden olur. ABD Liyakat Sistemini Koruma Kurulu (1981)'nun araştırmasında, kadınların \% 21-82'sinin taciz sonrasında psikolojik fiziksel verimlerinin düştüğü gözlenmiştir. Tacize hedef olan kadınlarda aşağılanmışlık, utanç ve suçluluk, güvensizlik, öfke ve endişe duyguları ortaya çıkar. Mağdurlar özel hayatlarında 
çok önemli problemler yaşayabilirler. Tacize hedef olan kadınlar başkalarıyla özellikle diğer erkeklerle ilişkilerinde doğallıkların kaybederler. Diğerleri tarafından yanlı̧ anlaşılma korkusu, suçlanma, işini kaybetme endişesi mağdurları susmaya iter.

Cinsel tacizin kadının işine ve kariyerine etkileri oldukça önemlidir. Cinsel taciz, hedefin stres düzeyini artırmaktadır. Renick (1980) tacize uğrayanların daha fazla kazaya eğimli olduklarını ve daha fazla hastalık izni aldıkların ifade etmektedir. Taciz, işyerlerinde ilişkilerin bozulmasına yol açabilir (DI TOMASO, 1989). Tacize uğrayan kimse, terfi ve ilerlemelerde önemli rol oynayan sosyal iletişim ağlarından uzaklaşır. Taciz olayı, tacizcinin diğer erkek çalışanlarla anlaşması ve hedefi tecrit etmesine de dönüşebilir. Taciz kadının işine yabanclaşmasına ve başarma azmini kaybetmesine yol açabilir. Çoğunlukla cinsel taciz kadının tecrübe kazandığı işini değiştirmesi ya da aynu is yerinde başka bir bölüme geçmesiyle sonuçlanmaktadır. Böyle bir sonucun kadının kariyerini ve ilerleme şansını olumsuz etkilediği açıktır. Araştırmalardan ortaya çıkan sonuç kadınların onda birinin cinsel taciz nedeniyle işten ayrıldığı yönündedir. Türkiye'de Ankara ve Denizli'de konfeksiyon iş̧̧lerini kapsayan araştırma, mağdurların \%6,8'inin taciz dolayısıyla işlerini değiştirdiklerini ortaya koymuştur (TÜBA, 1993).

Cinsel tacize uğrama korkusu kadınları çalı̧̧ma hayatına girmekten caydurabilir, erkek egemen işlerden uzak durmasına sebep olabilir. Böylece kadınlar genellikle düşük statülü düşük ücreti işlere yönelerek toplumda zaten var olan mesleki ayrımı güçlendirirler. Kadınların taciz nedeniyle işten ayrılması, işverenlerin kadın işgücünün işe bağlılıklarının olmadığı yönündeki önyargılarını artırmaktadır.

\section{Tacizin Tacizci ve Diğer Çalışanlar Açısından Sonuçları}

Araştırmalar taciz mağdurunun yaşadıklarına karşıllı, tacizcinin önemli sonuçlarla karşılaşmadığını ortaya koymaktadır. Davidson ve Earnshow (1990) Ingiltere'de tacizciye yönelik en yaygin cezanun bir resmi veya resmi olmayan uyarı olduğunu bildirmektedirler. Adı geçen araştırmacıların görüştükleri personel müdürlerinin yarısından fazlası (\%54), tacizciye asla bir değişiklik yapılmazken, hedef olan kimsenin yerinin değiştirilmesinin daha büyük bir olasllk olduğunu belirtmişlerdir.

Kipnis (1990)'e göre önlenemeyen taciz daha sonraki taciz olayların teşvik etmektedir. Özellikle tacizci yetki sahibi biriyse ve davranı̧larıla ilgili geri bildirim almadığı takdirde, kendine ve haklılığına inancı artarak taciz davranı̧lanı sürdürecektir. Böyle bir durum diğer erkek çalışanları taciz konusunda cesaretlendirmektedir. 
Diğer mesai arkadaşları taciz nedeniyle ortaya çıan sonuçları şiddetlendirebilirler. Loy ve Steward (1984), iş arkadaşlarınun taciz mağdurlarını tecrit etme veya dışlama ve onları rahatsızlık verenler olarak görme eğiliminde oldukların belirtmektedir. Arkadaşlar cinsel tacizin resmiyete dökülmesi risklerinden dolayı mağdurun yanında yer almayı istememektedirler.

\section{Kurumsal Sonuçlar ve Kurumun Özelliklerinin Cinsel Taciz Üzerindeki Etkileri}

Cinsel taciz, işyerinde çalışanlar için düşmanca bir ortam yaratarak iş düzenini bozmakta ve üretkenliği azaltmaktadır. Cinsel tacizin ortaya çıardığı moral bozukluğu ve düşük verimlilik, iş kazaları, hastalık izinleri, iş değiştirme ve işten ayrılmalar işletmeler için katlanılması gereken ilave maliyetlerdir. $A B D$ Liyakat Sistemini Koruma Kurulu'nun 1994 yllında yaptığı hesaplamalarda, cinsel tacizin yarattı̆̆ düşük verimlilik, işgücü devri ve işe devamsızlığın artmasının işveren sıfatıyla federal hükümete yılda 163 milyon dolara mal olduğu bulunmuştur (USMSPB, 1994).

Toplumsal cinsiyet rollerinin hüküm sürdüğü, erkeklerin sayıca yoğun olduğu kurumlar cinsel tacize ortam hazırlamaktadırlar. Bir işte belli bir cinsiyet yüksek oranda ise ve iş dağllımı da cinsiyete göre yapılmışsa, o işyeri cinsel tacize potansiyel bir zemin yaratmaktadır. Erkeklerin baskın olduğu işlerdeki kadınlar çok fazla dikkat çekerler. İşyeri normlan, yöneticilerin astlarına karşı tutumlan ve uyguladıkları yönetim gücü tipleri, çalışma adetleri örgüt ikliminin cinsel tacize elverişli olup olmadığı konusunda çalışanlara fikir verir. Üst yönetimin taciz davranışarına göz yummaları çalışanları taciz konusunda cesaretlendirir (LARWOOD / GUTEK, 1984). Buna karşllk eşit istihdam politikasına sahip örgütler, cinsel tacizin tekrarlanma oranında düşme sağlayabilirler (LAFONTAINE / TREDEAU, 1986).

Iş yaşamında cinsel taciz sorununu, ilk olarak ciddi biçimde ele alan ABD'de bugünkü gelinen noktada çeşitli yasa ve uygulamalar ile cinsel ayrımcılık ve cinsel taciz için önlemler alınması yoluna gidilmektedir. Bu yasa ve uygulamalar işveren ve yöneticilerinde çeşitli düzenlemelere gitmeleri konusunda hassasiyet oluşturmuştur. ABD'deki bu gelişmeler 1985 'li yıllarda $B M, U C ̧ O ̈$ ve $A B$ gibi örgütlerin konuya ilgisini artırmıs ve üye ülkeler için yol gösterici nitelikli belgeler kabul edilmiştir. Diğer endüstrileşmiş ülkeler bu gelişmelere duyarsız kalamamış, bu ülkeler hukuklarında da 1980'lerde başlayan çeşitli düzenlemeler yer almış ve kamuoyu bilinci oluşmuştur (BAKIRCI, 2000).

Türkiye'de de basın ve kadın hareketlerinin gayretleriyle konuya ilgi artmaktadır. Ülkemizde cinsel taciz konusu, uluslararası belgeler, Anayasa $(\mathrm{m} .12,17,19,20)$, Medeni Kanun (m.23,24,24/a), Borçlar Kanunu (m. 47,49) ve 
Ceza Kanunu (m.414,415,416,419,421, 426,428,480,482,547,576) ile güvence altina alınmış olan kişilik haklarının ihlalidir. Ayrıca uluslararası belgeler ve Anayasanın 50. maddesi 2. fikrasına göre cinsel taciz iş̧̧ilerin elverişli şartlarda çalışma haklarının ihlalidir ve son olarak cinsel taciz yine uluslararası belgeler ve Anayasa ile güvence altına alınan çalışma hakkını (m.49/1) ve istenilen alanda çalışma özgürlüğünü (m.48/1) kısıtlayan bir eylemdir (BAKIRCI, 2000).

\section{Uygulama}

\section{1. Çalışmanın Amacı, Kurgulanması ve Yöntem}

Çalışma amaçlarımız, birinci olarak, bankacilık sektöründe yaşanan cinsel taciz sorununun boyutların ortaya koyabilmek ve kadınların cinsel taciz karşısında durumların yansıtabilmek; ikinci olarak erkeklerin hangi koşullarda tacizi kadınlara karşı kullandıklarını ve işyerinde güç ilişkilerinin tacize nasıl bir fırsat yarattığın belirlemek; üçüncü olarak banka amirlerinin taciz olaylarına yaklaşımın ve bankaların cinsel tacizi önlemeye yönelik politikalarını saptamak ve son olarak işyeri yöneticilerine ve kurum politikalarına yardımcı olacak önerileri sunarak toplumda konuya duyarlılık oluşturmaya katkıda bulunmaktır.

Bankacllk sektörü 1980'den sonra yapılan mevzuat düzenlemeleriyle huzla büyüyen ve dinamizm kazanan ve kadınlarn yoğun bir biçimde istihdam edildiği alanlardan biridir. Türkiye Bankalar Birliği verilerine göre, 1994 yılında özel kesim bankalarında çalışanların \%39'unu ve kamu bankalarında çalışanların \%33'ünü kadınlar oluşturmaktaydı. Bu oranlar yıldan yıla kadınlar lehine artış göstermiş, 2000 yılında sırasıyla \%48 ve \%47'ye çıkmıştır. Son ylllarda bankacilık sektöründeki gelişmelerle birlikte bankaların sunduğu olanaklar ve çalışma koşulları nedeniyle nitelikli kadın işgücünün giderek artan şekilde iş talebinde bulunduğu kaydedilmektedir (EYÜBOĞLU vd., 2000; TBB, 2001).

Araştırmamızda, özel-kamu bankası ayrımı yapılmaksızın, Erzurum ilinde faaliyet gösteren banka bölge müdürlükleri ve şubelerinin çeşitli kademelerinde görev yapan kadın personel ana kütle olarak alınmıştır. Araşturmanun ana kütlesini 11 ticari bankanun 4 bölge müdürlüğü ve 20 şubesi oluşturmaktadır. Toplam 4 şubeye sahip 3 banka araşturmanun dışında kalmıştır. Elde edilen veriler ana kütlenin tümünü temsil edecek niteliktedir.

$\mathrm{Bu}$ çalışmada veri toplama tekniği olarak anket uygulaması tercih edilmiştir. Genelde kadın araştırmalarında bu tür konular güven ortamının daha kolay tesis edilebileceği bireysel ya da gruplar ile görüşme gibi niteliksel teknikler aracılığıyla incelenmesine rağmen, birçok denekle yapılan ön görüşmede denekler konuya ilişkin sorulara isimsiz anketlerde daha doğru 
cevaplar verilebileceğini belirtmişlerdir. Nitekim, yapılan ön görüşmelerde bazı cinsel taciz olaylan üst yöneticiler tarafından -saklı kalmak kaydıyla- aktarılmış, oysa ilgili mağdurlar yüz yüze görüşmede tacizle hiç karşlaşmadıklarını ifade etmişlerdir. Bu tutumda, muhafazakar değerlerin baskın olduğu dar çevrede tanudık ilişkilerin yaygınlığı nedeniyle "olay"ın duyulabileceği endişesinin önemli etken olduğu düşünülmektedir. Dolayısıyla veri toplama tekniği olarak anket uygulanması yoluna gidilmiştir. Yine de, deneklere cevapların gizliliği konusunda söz verilmesine ve ikna etmeyi amaçlayan yazılı açıklamaya rağmen, konunun rahatsız edici olması ve kadınların bu konuda susmayı tercih etmeleri gibi nedenlerle bazı cevaplarda samimi davranılmadığı anlaşlmaktadır. Ancak takip eden soruların birbirini test eder ve tamamlar nitelikte oluşu nedeniyle anlamlı sonuçlar elde edilmeye çalışılmıştır.

Araşturma kapsamında 100 anket formu deneklere elden verilmiştir. Cevaplanan anket formu sayısı 82 'dir. 20 sorudan oluşan ankete verilen cevaplardan elde edilen veriler SPSS paket programı ile analiz edilmiştir. Elde edilen bazı veriler arasında anlamlı ilişkilerin saptanması için Ki-Kare sınamaları yapılmıştır.

\section{Araştırmanın Hipotezleri}

1- Bankacllık sektöründe, diğer sektörlerde olduğu gibi cinsel taciz olayları sıkça yaşanmaktadır.

2- Kadın personel ast konumundayken daha çok taciz riski yaşamakta, üst pozisyonlarda bu risk azalmaktadır.

3- Erkekler resmi statülerinden aldıkları gücü kadına karşı taciz amacıyla kullanabilmektedirler.

4- Tacizde bulunan erkekler sadece resmi statülerini değil, sahip oldukları informal güç kaynaklarını da kadına karşı taciz amaçlı kullanabilmektedirler.

5- Tacizde bulunan erkekler çoğunlukla evli ve hedeflerinden daha yaşlı kimselerdir.

6- Tacize hedef olan kadınlar psikolojik ve sosyolojik nedenlerle tacizi açığa vurmak istemezler.

7- Kadının aldığı eğitim, taciz karşısında susmak ya da konuyu şikayet etmek şeklindeki eğilimleri değiştirmemektedir.

8- Cinsel taciz kadının verimini önemli ölçüde olumsuz etkilemektedir.

9- Toplumda bazı meslek gruplarında kadının daha çok tacize uğrayacağı yönünde anlayıs vardır. 
10- Taciz olaylarında genellikle tacizde bulunan erkeklere hiçbir işlem yapilmamaktadır.

11-Bankalarda tacizi önlemeye yönelik uygulamalar söz konusu değildir.

\section{Verilerin Analizl}

Uygulanan anketlerin bilgisayar ortaminda analiz edilmesiyle elde edilen veriler ve bu verilere göre yapılan yorumlar aşağıdaki gibidir:

Tablo 1: Ilde Bayan Bankacı Ozellikleri

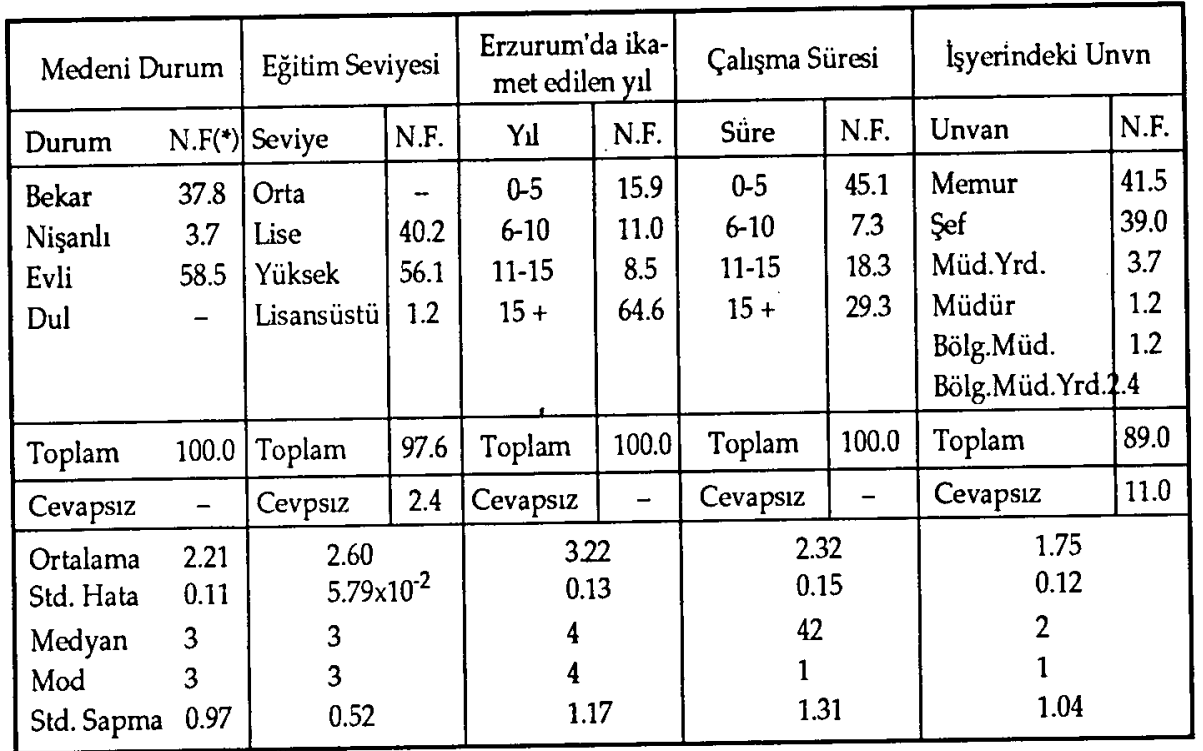

(*) N.F. Nispi Frekans (\%)

Erzurum'da bankalarda çalışan kadın personele ait özellikleri yansıtan tablodan, kadınların yarıdan fazlasının evli olduğu $(\% 58,5)$, bekarların ikinci sırada yer aldığı, dul kadına hiç rastlanmadığı anlaşılmaktadır. Taciz daha çok dul, kocasından ayrılmıs ve yalnız yaşıyan kadınlara yöneltilmiş bir davranı̧ olduğundan, çalışmamızda bu durum cinsel taciz riskini azaltan bir faktör olarak düşünülebilir.

Bankacı kadınların büyük bir çoğunluğu yüksek eğitim almıştır $(\% 56,1)$. Lisansüstü eğitim yapanlarla birlikte bu oran $(\% 57,3)$ tür. Geriye kalan çalışanların lise mezunu $(\% 40,2)$ oldukları görülmektedir. Ortaokul mezunu kadın personel yoktur. 
Erzurum'da geçirilen süre itibariyle 15 yll ve daha fazla ilde oturanlar en büyük çoğunluğu oluşturmaktadır. Genellikle 15 yıldan daha fazla süre ilde ikamet edenlerin Erzurum doğumlu oldukları söylenebilir.

Ünvanlarla ilgili elde edilen bilgilerden, ildeki bankalarda oranlar çok düşük olsa da bölge müdürü, bölge müdür yardımcısı, müdür ve müdür yardiması pozisyonlarında kadınları görmek memnuniyet vericidir. Burada dikkat çeken husus ildeki banka şube sayıları göz önüne alındığında kadın şube müdürü ve müdür yardımcılarının çok düşük oranda kalmasıdır. Bu durum kadın şube müdürlerinin müşteri ilişkilerinde (dışarıda yemek gibi) tacizle karşılaşabilecekleri ihtimaline karşılık bu pozisyona yükseltilmemeleri ile açıklanabilir veya kadınların orta kademelerde açkça görülmeyen (cam tavan) engeli ile karşılaştıkları söylenebilir. Çünkü tablodaki bilgilerde memur $(\% 41,5)$ ve şef $(\% 39,0)$ oranlarınun neredeyse eşit olması, cinsiyetin alt kademe yöneticiliğe terfilerde sorun olmadığını göstermektedir.

Tablo 2: Aşağıdaki Dauranışlardan Hangisi Cinsel Taciz Olarak Algılanır

\begin{tabular}{|l|c|c|}
\hline Davranış Şekilleri & M.F. $\left(^{*}\right)$ & N.F. \\
\hline Söz atma & 10 & 12.2 \\
Islık çalma & 1 & 1.2 \\
Yolda takip etme & 5 & 6.1 \\
Çirkin davetler, imalar & 20 & 24.4 \\
Küfür & 3 & 3.7 \\
Müstehcen Sözler & 13 & 15.9 \\
Rahatsız edici konuşmalar & 23 & 28.0 \\
Açık-saçık fıkralar & 9 & 11.0 \\
Telefonla rahatsız etme & 9 & 11.0 \\
Rahatsız edici bakış & 21 & 25.6 \\
El hareketleri, dokunma & 25 & 30.5 \\
Sarkıntılık & 16 & 19.5 \\
Sırnaşık hareketler & 15 & 18.3 \\
Müstehcen materyal sergileme & 6 & 7.3 \\
Irza tecavüz & 9 & 11.0 \\
Edebe ve iffete aykırı diğer hareketler & 18 & 22.0 \\
Hepsi & 49 & 59.8 \\
\hline
\end{tabular}

(*) M.F.: Mutlak Frekans

(*) Işyerinde kadınlar üst pozisyonlara giden yolda (daha çok orta kademelerde) anlaşılması ve anlatılması zor örgütsel engellerle karşılaştılar. Cinsiyet ayrımcılığından kaynaklanan bu engellere "cam tavan" denilmektedir (GERNI, 2000). 
Cinsel taciz olarak algılanabilecek en hafifinden en şiddetlisine kadar suralanan davranışlardan; hepsinin taciz olduğu şeklindeki görüş $(\% 59,8)$ birinci suradadır. Sonra surasiyla el hareketleri ve dokunma $(\% 30,5)$, rahatsiz edici konuşmalar $(\% 28)$, çirkin davetler ve imalar $(\% 24,4)$ taciz olarak öncelikle algılanan davranışlar olarak görülmektedir. Oysa hiç kimsenin tereddüt etmeden cinsel taciz diyebileceği rrza tecavüz (\%11) taciz davranşı olarak son sıralarda kabul edilmiştir. Bunun nedeni kadınların değil karşllaşmaktan, telaffuz etmekten ve işaretlemekten bile ürktükleri bir eylem olarak görülmesi olabilir.

Tablo 3: Taciz Olarak Bilinen Dauranış(lar) ile Karşılaşıllı Karşılaşmama Durumu

\begin{tabular}{|l|c|c|}
\hline Karşılaşma Durumu & M.F. & N.F. \\
\hline Evet; karşlaş̧ı & 29 & 35.4 \\
Hayır; karşıllaşmad 1 & 49 & 59.8 \\
\hline Toplam cevaplama & 78 & 95.1 \\
\hline Cevapsız & 4 & 4.9 \\
\hline Ortalama & \multicolumn{2}{|c|}{1.63} \\
Std.Hata & \multicolumn{3}{|c|}{$5.51 \times 10-2$} \\
Medyan & \multicolumn{3}{|c|}{2} \\
Mod & \multicolumn{3}{|c|}{0.49} \\
Std.Sapma & \multicolumn{3}{|c}{} \\
\hline
\end{tabular}

Taciz olarak algılanan davranşlarla karşlaş̧ı karşılaşmadıkları ile ilgili soruya kadınların büyük bir çoğunluğu (\%59.8) karşılaşmadıklarını ifade etmektedirler. Oysa taciz davranı̧larıyla karşlaşmadıkların ifade edenlerin bir kısmı daha sonraki sorularda tacizle karşılaştıkların gösterir cevapları işaretlemişlerdir. Bu durum kadınların tacizi çok zor dile getirilebilmelerinden kaynaklanmaktadır. İtiraf edememe, kadının toplumda taciz nedeniyle suçlanması ve kendini aşağllanmış hissetmesi yönündeki bulgulara da uygun düşmektedir. Ayrıca dört kişi bu soruyu cevapsız bırakmıştır. Sonuç olarak tacizle karşılaştım diyenlerin sayısı $(\% 35,4)$ aslında çok daha fazla olarak anlaşılmaktadır.

Ayrıca kadın bankacların özellikleri ile (medeni durumları, eğitim seviyeleri, çalı̧̧ma süreleri, ilde ikamet edilen süre) tacize hedef olma arasında anlamlı farklılıkların olup olmadığı Ki-Kare sınamaları ile araştırılmış ve istatistiki açıdan anlamlı ilişkiler bulunamamıştır. Yani medeni durum, eğitim 
seviyesi, çalışma süresi ve ikamet edilen süreler ne konumda olursa olsun, taciz olgusunun varlığı değişmemektedir. Daha açık bir ifade ile, örneğin medeni durum ile tacize uğrama arasında anlamlı bir farklılık görülmemiştir.

Tablo 4: Tacizle Karşılaştırılmışsa, Tacizin Ne Tür Olduğu

\begin{tabular}{|l|c|c|}
\hline Davranı̧ Şekilleri & M.F. & N.F. \\
\hline Söz atma & 16 & 19.5 \\
Islık çalma & 7 & 8.5 \\
Yolda takip etme & 9 & 11.0 \\
Çirkin davetler, imalar & 3 & 3.7 \\
Küfür & 6 & 7.3 \\
Müstehcen Sözler & 10 & 12.2 \\
Rahatsız edici konuşmalar & 29 & 35.4 \\
Açık-saçık fikralar & 9 & 11.0 \\
Telefonla rahatsız etme & 6 & 7.3 \\
Rahatsız edici bakış & 23 & 28.0 \\
El hareketleri, dokunma & 12 & 14.6 \\
Sarkıntılık & 2 & 2.4 \\
Sırnaşı hareketler & 13 & 15.9 \\
Müstehcen materyal sergileme & - & - \\
Irza tecavüz & - & - \\
Edebe ve iffete aykırı diğer hareketler & 2 & 2.4 \\
Hepsi & - & - \\
\hline
\end{tabular}

Kadınlar karşılaştıkları taciz davranı̧̧ları olarak birinci sırada rahatsız edici konuşmaları $(\% 35,4)$, ikinci ve üçüncü sırada rahatsız edici bakışları $(\% 28)$ ve söz atmayı $(\% 19,5)$ göstermişlerdir. Irza tecavüz ve müstehcen materyal sergileme davranışları dışında kadın bankacıların her türlü taciz davranışlarıyla yüz yüze geldiği söylenebilir.

Tablo 5: Işyerinde Tacizde Bulunan Kaç Kişiyle Karşılaşunız

\begin{tabular}{|c|c|c|}
\hline Kişi Sayısı & M.F. & N.F. \\
\hline 1 & 4 & 4.9 \\
2 & 7 & 8.5 \\
3 & 1 & 1.2 \\
4 & - & - \\
5 & - & - \\
6 & 1 & 1.2 \\
\hline Toplam cevaplama & 13 & 15.9 \\
\hline
\end{tabular}


Işyerinizde tacizde bulunan kaç kişiyle karşılaştunuz sorusuna verilen cevaplardan çoğunluğun iki veya daha fazla kişi tarafından taciz edildiği anlaşılmaktadır. Altı kişi tarafından taciz edildiğini ifade eden cevap da vardır. Kadınların çoğunun birden fazla kişi tarafından taciz edilmesi, aslında tacize uğrayanların oranunun yukarıda ifade edilenden daha fazla olduğu ihtimalini kuvvetlendirmektedir. Ayrıca tacizle karşlaşım diyen \%35,4'lük orana karşllık, işyerinde taciz eden kaç kişiyle karşılaştınız sorusuna cevap verenlerin oran $\% 15,9^{\prime}$ dur. Bunun dışındakilerin müşteriler tarafından $\mathrm{m}$, yoksa farklı bir işyerinde çalışırken mi taciz yaşadıkları anlaşılamamaktadır. Bu sonuç yine kadınların taciz konusunu rahat konuşamamaları ile ilgili olabilir.

Tablo 6: Tacizde Bulunan Kişinin Yaş Durumu

\begin{tabular}{|l|c|c|}
\hline Yaş Durumu & M.F. & N.F. \\
\hline Yaşça denk & 1.5 & 18.3 \\
\hline Yaş̧a küçük & 6 & 7.3 \\
\hline Yaşça büyük & 33 & 40.2 \\
\hline
\end{tabular}

Tacizde bulunan kişilerin yaşların belirten cevaplarda hedeflerinden yaşca büyükler $(\% 40,2)$ birinci sırada, eşit yaşlarda olanlar $(\% 18,3)$ ikinci sırada ve yaş̧a küçükler $(\% 7,3)$ son sırada yer almaktadır.

Tablo 7: Tacizde Bulunan Kişinin Medeni Durumu

\begin{tabular}{|l|c|c|}
\hline Yaş Durumu & M.F. & N.F. \\
\hline Evli & 28 & 34.1 \\
\hline Bekar & 2 & 2.4 \\
\hline Dul & - & - \\
\hline
\end{tabular}

Tacizde bulunan kişilerin evli olup olmadığı ile ilgili soruya verilen cevaplarda tacizde bulunan erkeklerin neredeyse hepsinin $(\% 34,1)$ evli olduğu anlaşılmaktadır. Bekarların oranı sadece $(\% 2,4)$ 'tür. Tablo 6 ve 7 birlikte ele alındığında elde edilen veriler, tacizde bulunan erkeklerin çoğunlukla evli ve hedeflerinden daha yaşlı olduğu şeklindeki araştırma bulguları ile uyuşmaktadır. Bu durum taciz eyleminin romantik bir ilişki talebi olmadığı, kadını kullanma amac güttüğü yolundaki varsayımlarla tutarlıdır. 
Tablo 8: Tacizde Bulunulan Kişinin Unvanı

\begin{tabular}{|l|c|c|}
\hline Unvan & M.F. & N.F. \\
\hline Memur & 17 & 20.7 \\
Şef & 2 & 2.4 \\
Müd.Yrd. & - & - \\
Müdür & - & - \\
Bölg.Müd. & - & - \\
Bölg.Müd.Yrd. & - & - \\
\hline
\end{tabular}

Tacize hedef olan kadınlann taciz sırasındaki ünvanlarının ne olduğu ile ilgili soruya verilen sadece iki tip cevapta, birinci surada memur $(\% 20,7)$ ikinci sırada şef $(\% 2,4)$ cevabı yer almaktadır. Sonuçlar kadınların üst pozisyonlarda tacize uğramadığı şeklinde gözükmekle beraber, doğru yoruma ulaşabilmek için kadınların bu pozisyonlarda çok düşük oranda bulunmasını da göz önünde tutmak gerekmektedir. Bununla beraber bankalarda memur ve şef kadrosunda birikmiş kadınların taciz olayları ile en fazla memurken karşılaştıklarını, şefken çok az karşılaştıklarını ifade etmeleri yapılan araştırma sonuçlarına uygun düşmektedir. Erkekler resmi statülerinden aldıkları güçle ast konumundaki kadınlardan cinsel talepte bulunmayı haklan olarak görebilmektedirler.

Tablo 9: Tacizde Bulunan Kişinin Bu Dauranışı Tekrarlama Durumu

\begin{tabular}{|l|c|c|}
\hline Tekrarlama Durumu & M.F. & N.F. \\
\hline Evet; tekrarladı & 15 & 18.3 \\
Hayır; tekrarlamadı & 21 & 25.6 \\
\hline
\end{tabular}

Tacizde bulunulan kişilerin bu davranş̧ları tekrarlayıp tekrarlamadıkları ile ilgili soruya tekrarlamadı cevabı \%25,6 oranunda birinci sırada, tekrarladı diyenlerin cevabı $\% 18,3$ ile ikinci siradadır. 
Tablo 10: Tacizde Bulunan Kişinin Kurumdaki Konumlan

\begin{tabular}{|l|c|c|}
\hline Unvan & M.F. & N.F. \\
\hline Üst & 15 & 18.3 \\
Ast & 13 & 15.9 \\
Eşit & 8 & 9.8 \\
Müşteri & 17 & 20.7 \\
\hline
\end{tabular}

Tacizde bulunan kişilerin size (hedefe) göre konumları nedir sorusuyla ilgili cevaplarda birinci sırada müşteriler $(\% 20,7)$ ikinci sırada üstler $(\% 18,3)$, üçüncü sırada astlar $(\% 15,9)$ ve son olarak eşit konumdakiler $(\% 9,8)$ cevabı yer almaktadır. Bu sonuca bakılarak kadın bankacıların en fazla müşteriler tarafından rahatsız edildiği söylenebilir. Çalışma arkadaşları olarak en çok üstlerden taciz görülmesi beklenen cevaptır. Çünkü iş ortamında, güç ilişkilerinin söz konusu olduğu durumlarda cinsel taciz güçlünün zayıf üzerinde kontrol sağlama araçlarından biri olarak karşımıza çıkmaktadır.

Tablo 11: Tacizde Bulunan Kişinin Kurumda Ast veya Eşitse, Sahip Olduklan Güç Kaynağının Olup Olmama Durumu

\begin{tabular}{|l|c|c|}
\hline Güç Kaynakları & M.F. & N.F. \\
\hline Amire ve üst kademelere yakınlık & 11 & 13.4 \\
Kurum içerisinde sosyal gruplar içerisinde bulunmakta & 2 & 2.4 \\
Ideolojik ve benzeri gruplara yakınlık & 2 & 2.4 \\
Hiçbiri & 20 & 24.4 \\
\hline
\end{tabular}

Tacizde bulunan ast veya eşit konumdaki kişilerin resmi statüleri dışında güç kaynaklarına sahip olup olmadıkları yönündeki soruya, hiçbir güç kaynağına sahip olmadıkları cevabı birinci suradadır (\%24,4). Ancak daha sonra sırasıyla üst kademelere yakınlık (\%13,4), kurum içinde sosyal gruplar içinde bulunma $(\% 2,4)$, ideolojik ve benzeri gruplara yakınlik $(\% 2,4)$ ile toplam $(\% 18,2)$ 'lik cevap, tacizde bulunanların önemli bir kısmının bir takım güc kaynaklarına sahip oldukların ortaya koymaktadır. Bu araştırma bulgularına uyan bir sonuçtur. Çünkü astlar veya eşit konumdaki erkekler, hedefin sahip olmadığı informal güç kaynaklarına sahip oldukları zaman bu güce dayanarak cinsel tacizi kadına karşı kullanabilirler veya kadına cinsel kimliğini hissettirerek onu zaylf bir duruma sokmak yoluyla güç elde etmek için cinsel tacizi kullanabilirler. 
Tablo 12: Taciz Karşısında Takınılan Tutum

\begin{tabular}{|l|c|c|}
\hline Takınılan Tavır & M.F. & N.F. \\
\hline Sessiz kalmak & 8 & 9.8 \\
Tacizciye tepkide bulunmak & 8 & 9.8 \\
Durumu yakın arkadaşlarla paylaşmak & 12 & 14.6 \\
Amiri bilgilendirmek & 1 & 1.2 \\
Olayı adli mercilere intikal ettirmek & - & - \\
\hline
\end{tabular}

Taciz karşısında kadınların nasıl bir tutum sergilediklerini gösteren cevaplardan sadece $(\% 1,2)$ 'si amirine durumu anlatabilmiştir. Tacizciye tepki verenlerin oran da $(\% 9,8)$ fazla değildir. Sessiz kalan $(\% 9,8)$, durumu yakın arkadaşlarıyla paylaşan $(\% 14,6)$ ile beraber kadınların çok büyük bir çoğunluğunun tacizi şikayet etmedikleri ve sineye çektikleri söylenebilir. Bu durum araşturma bulgularına uygun düşen bir sonuçtur. Türkiye gibi geleneksel değerlerin korunduğu bir ülkede kadının tacizi dışa vurması çok daha zordur. Genellikle taciz gizlenemeyecek boyutlarda yaşanyorsa, şikayet konusu edilebilmektedir.

Ki-Kare sınamasıyla kadınların aldığı eğitim ile taciz karşısında takındıkları tutum arasındaki ilişkiler araştırılmıs, ancak istatistiki açıdan anlamlı farklılıklar bulunamamıştır. Araştırmamızda alınan eğitimin taciz karşısındaki eğilimleri değiştirmediği sonucuna varılmıştır.

\section{Tablo 13: Taciz Karşısında Sessiz Kalınma Nedenleri}

\begin{tabular}{|l|c|c|}
\hline Takınılan Tavır & M.F. & N.F. \\
\hline Utanmak & 2 & 2.4 \\
Yanlı̧ anlaşılmaktan korkmak & 10 & 12.2 \\
Dışlanma korkusu & - & - \\
Suçluluk duygusu & - & - \\
İşle ilgili engellerle karşılaşma korkusu & 1 & 1.2 \\
\hline
\end{tabular}

Kadınlar taciz karşısında sessiz kalmalarının nedeni olarak en başta yanlış anlaşılmaktan korkmalarını $(\% 12,2)$ göstermişlerdir. Tacize erkeği cesaretlendirerek kadının yol açtı̆̆ şeklindeki toplumda yerleşmiş anlayış 
dolayısıyla kadınlar suçlanmamak için susmayı tercih etmektedirler. Taciz mağduru kadın tacizi konuştuğu ya da şikayet ettiği takdirde çok daha ağır maliyetlerle karşılaşmaktadır. Taciz olayının büyüyerek çevrede duyulması durumunda çalışma arkadaşlan mağduru iş huzurunu bozan olarak görmek ve dışlamak eğilimindedirler. Mağdurun aile ortamında yaşayabileceği sorunlar da düşünüldüğünde mağdurlar taciz olayın kendi içlerinde yaşamakta, en fazla güvendikleri arkadaşları ile paylaşmaktadırlar.

Ayrıca kadınların sessiz kalma nedeni olarak ikinci sırada utanç duyma $(\% 2,4)$, üçüncü sırada işle ilgili mesleki engellerle karşılaşma korkusu $(\% 1,2)$ verilen cevaplardır. Araştırmamıza konu olan kadınlarda resmi bir şikayet söz konusu olmadığı için arkadaşlanı tarafından dışlanma endişesi yaşamadıkları anlaşılmaktadır.

Tablo 14: Tacizin Amire lletilmesi Karşısında Amirin Takındığı Tutum

\begin{tabular}{|l|c|c|}
\hline Takınılan Tavır & M.F. & N.F. \\
\hline Duygularımı paylaşı, tavsiye verdi & 5 & 6.1 \\
Tacizde bulunana sözlü ikaz yaptı & - & - \\
Görev yerimi değiştirdi & - & - \\
Taciz edenin görev yerini değiştirdi & - & - \\
Tacizde bulunana resmi işlem yaptı & - & - \\
Hiçbir şey yapmadı, duyarsız kaldı & 7 & 8.5 \\
\hline
\end{tabular}

"Tacizi amirinize ilettiniz ise amirinizin bu durum karşısındaki tepkisi ne oldu" sorusuna verilen cevaplar fazla çeşitlilik göstermemektedir. Verilen sadece iki tip cevaptan "hiçbir şey yapmadı, duyarsız kaldı" diyenler $(\% 8,5)$ birinci sırada, "duygularımızı paylaştı ve tavsiye verdi" cevabı $(\% 6,1)$ ikinci sıradadır. Belki bankalarda taciz olaylarının çok şiddetli boyutlarda yaşanmamış olması ve mağdurun mahremiyet sınırları içerisinde hareket etmesi gibi nedenler amirlerin tacizcinin görev yerini değiştirme ve resmi işlem yapma gibi davranışlarda bulunmasın engelleyebilir. Ancak yaşanan bir çok taciz durumlarından tek birinde bile amirin taciz yapana hiçbir ikazda bulunmaması ilginç bir sonuçtur. Bu sonuç tacizde bulunanlara hiçbir şey yapılmadığ yönündeki diğer araştırma sonuçlarına uygun düşmektedir. 
Tablo 15: Taciz Olayını Bilen Arkadaşlarınızın Takındığı Tutum

\begin{tabular}{|l|c|c|}
\hline Takınılan Tavır & M.F. & N.F. \\
\hline Beni desteklediler & 16 & 19.5 \\
Beni haksız buldular & - & - \\
Olayın dışında kalmak istediler & - & - \\
Beni dışladılar & - & - \\
Taciz edeni dışladılar & 3 & 3.7 \\
Her birinin tepkisi farklı oldu & 2 & 2.4 \\
\hline
\end{tabular}

Taciz olayını öğrenen arkadaşların mağdura karşı tutumlarının daha çok destekleme olduğu yönünde birinci surada $(\% 19,5)$ yer alan cevap diğer araştırma sonuçlarına fazla uygun değildir. Fakat önceki verilen cevaplarda herkesin duyabileceği çok büyük boyutlarda bir taciz yaşanmadığı ve mağdurların tacizi resmi şikayete dökmedikleri sadece kendini çok iyi tanyan samimi arkadaşları ile paylaştıkları düşünülürse diğerlerinin haksız bulması, đışlanması gibi hususlar söz konusu olmayacaktır. Çok düşük oranlarda da olsa $(\% 3,7)$ taciz edenin dışlandığı cevabı ilginçtir. Bu tepki çok yakın arkadaşların gösterebileceği normal bir tavır olarak düşünülebilir.

Tablo 16: Taciz Dauranışının Verimliliği Etkileme Durumu

\begin{tabular}{|l|c|c|}
\hline Verimliliğe Yansıması & M.F. & N.F. \\
\hline Etkilemedi & 5 & 17.2 \\
Az etkiledi & 7 & 24.1 \\
Etkili oldu & 13 & 44.8 \\
Çok fazla etkiledi & 4 & 13.8 \\
\hline
\end{tabular}

"Tacizin verimliliğiniz üzerindeki etkisinin ne olduğu" sorusuna birinci surada $(\% 44,8)$ "etkilendim", ikinci sırada $(\% 24,1)$ "az etkilendim", üçüncü sirada "etkilenmedim" $(\% 17,2)$ ve son sırada "çok fazla etkilendim" diyenlerin cevabı gelmektedir. Tacizden çeşitli derecelerde "etkilendim" diyenlerin toplam olarak oran $(\% 82,7)$, "etkilenmedim" diyenlerden $(\% 17,2)$ çok fazladır. Araştırmalar da tacizin kadının stres düzeyini artırdığın, psikolojik, fiziksel ve ekonomik verimliliklerini düşürdüğünü ortaya koymaktadır. 
Tablo 17: Işyerinde Diğer Arkadaşlannıza Yönelik Taciz Olayının Olup Olmaması

\begin{tabular}{|l|c|c|}
\hline Arkadaşlara yönelik taciz & M.F. & N.F. \\
\hline Evet; var & 28 & 46.3 \\
Hayı; yok & 31 & 37.8 \\
\hline Toplam & 69 & 84.1 \\
\hline Cevapsız & 13 & 15.9 \\
\hline
\end{tabular}

Işyerinizde diğer arkadaşlarınıza yönelik taciz olayının olup olmadığı ile ilgili soruya en fazla cevap \%46,3 ile evet şeklindedir. Hayır duymadım diyenlerin oranı \%37,8'dir. Görüldüğü gibi kadınlar tacizi kendi başlarına geldiği takdirde çok kolay itiraf edemezlerken, başkalarıla ilgili soruyu daha rahat cevaplayabilmişlerdir.

Tablo 18: Taciz Riski Daha Yüksek Meslekler (En risklileri)

\begin{tabular}{|l|c|c|}
\hline Meslekler & $\begin{array}{c}\text { Toplam olarak riskli } \\
\text { bulma sayıları }\end{array}$ & $\begin{array}{c}\text { Birinci derecede } \\
\text { önemli bulma sayları }\end{array}$ \\
\hline Sekreter & 22 & 9 \\
Hemşire & 20 & 9 \\
Manken & 16 & 9 \\
Hostes & 16 & 6 \\
Tezgahtar, pazarlamacı & 14 & 3 \\
Erkeğin olduğu her iş kolu & 8 & 7 \\
\hline Toplam & - & 52 \\
\hline Cevapsız & - & 30 \\
\hline
\end{tabular}

Taciz riski en fazla olan meslekler olarak birinci sırada sekreterlik, ikinci sırada hemşirelik, üçüncü sırada mankenlik gösterilmektedir. Ilk iki sırada taciz riski en fazla olan mesleklerin sekreterlik ve hemşirelik olarak gösterilmesi toplumun genel anlayışı doğrultusunda verilen cevaplardır. Mankenliğin de risk suralamasında öncelikli meslek olarak belirtilmesi, bu meslek mensuplarının topluma paralel düşmeyen özel hayatlarına medyanın aşın ilgisinden kaynaklanmış olabilir. 
Tablo 19: Işyerinde Cinsel Tacizi Onlemeye Yönelik Politikalann Varlığı

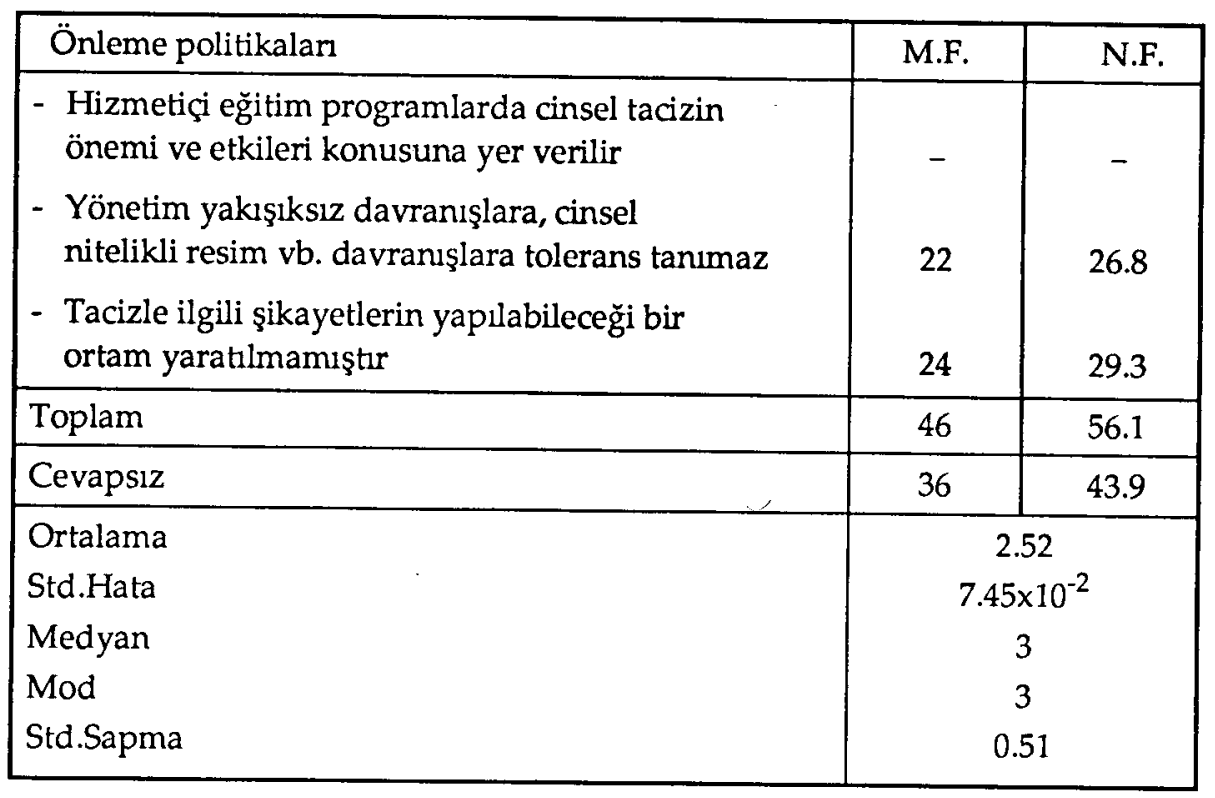

Işyerinde cinsel tacizi önlemeye yönelik politikaların olup olmadığı ile ilgili soruya verilen cevaplarda sözü edilen bankalarda cinsel tacizi önlemeye yönelik ciddi politikaların olmadığı anlaşılmaktadır. Cevaplardan tacizle ilgili şikayetlerin yapılabileceği bir ortamın olmadığ 1 (\%29,3), cinsel tacizin önemi ve etkileri hakkında çalışanlara herhangi bir eğitimin verilmediği (\%0) anlaşılmaktadır. Sadece yönetimin yakışıksız davranışlara meydan vermediği ve hoş görmediğinin belirtilmesi $(\% 26,8)$ kadınlar açısından olumlu bir durum saylabilir. 
Tablo 20: Cinsel Taciz Riskinin Statüdeki Yäkselmeyi Engellediğine Olan Inanç

\begin{tabular}{|l|c|c|}
\hline Inanç Durumu & M.F. & N.F. \\
\hline Evet; yükselmek problemdir & 5 & 6.1 \\
Fikri yok & 7 & 8.5 \\
Hayır; problem değildir & 56 & 68.3 \\
\hline Toplam & 68 & 82.9 \\
\hline Cevapsız & 14 & 17.1 \\
\hline Ortalama & \multicolumn{2}{|c|}{2.75} \\
Std.Hata & \multicolumn{2}{|c|}{$3.07^{2}$} \\
Medyan & 3 \\
Mod & \multicolumn{2}{|c}{0.58} \\
Std.Sapma & \multicolumn{2}{|c|}{} \\
\hline
\end{tabular}

"İsyerinde konumun-statünün yükselmesi (şef, müdür yardımcısı, müdür, vb.) halinde taciz riskinin artması (müşterilerle birebir görüşme, yemek, toplantı gibi ortamlann zorunluluğu) ihtimaline karşı, yükseltilmenin bir problem olabileceğine inanyor musunuz" sorusuna büyük bir çoğunluk $(\% 68,3)$ hayır cevabını vermiştir. Ikinci olarak fikri olmayanlar $(\% 8,5)$ ve üçüncü olarak yükselmenin problem olacağın düşünenlerin $(\% 6,1)$ cevabı gelmektedir. Bu sonuç kadınların en çok alt konumda (memur) iken, cinsel tacize hedef oldukların belirtmeleriyle uygunluk göstermektedir. Bu durumu yine işyerindeki güç ilişkisi çerçevesinde yorumlamak mümkündür.

\section{Sonuç ve Ōneriler}

Bankaların çahşma koşullannın (iş hacminin yoğunluğu, çalışmanın çoğunlukla duvarlarla bölünmemiş bir salonda yapılması ve en önemlisi bankacılığın neredeyse bir kadın çalışma alanı ve kadınlann sayıca çok yoğun olduğu bir sektör olması) kadınlar için cinsel taciz ortamı yaratmayacağı beklentisine rağmen, çalışmamızın sonuçları bankacı kadınlar için cinsel tacizin önemli bir sorun olduğunu ortaya koymuştur.

Bankalarda taciz davranışı kadınlardan daha üst pozisyonda bulunan kişilerden gelmektedir. Bu sonuç gü̧ sahibi olmanun cinsel taleplerde bulunmada erkeği cesaretlendirdiğini ortaya koymaktadır. Başka bir ifadeyle erkekler resmi statülerini kadınlara karşı yanlş amaçlarla kullanabilmektedirler. Benzer şekilde ast veya eşit konumdaki erkeklerin de resmi statüleri dışında 
sahip oldukları güç kaynaklarını kadınlara karşı cinsel amaçlı kullanabildikleri anlaşılmaktadır.

Bankalarda kadınların üst pozisyona yükseltilmeleri cinsel tacizle karşılaşma olasılığını azaltmaktadır.

Tacizde bulunan erkeklerin hedeflerinden daha yaşı ve evli oldukları belirlenmiştir. Bu sonuç cinsel tacizin kadını istismar amaçlı olduğunu ortaya koymaktadir.

Çalışmaya konu olan kadınlar, dünyadaki diğer hemcinsleri gibi cinsel tacizi şikayet etmemekte, çoğunlukla sessiz kalmayı tercih etmektedirler. Bunda en önemli etken toplumda tacize müsait olan kadınlann hedef olacağı şeklinde yerleşmiş anlayıştan dolayı, yanlış değerlendirilme korkusudur.

Kadınların eğitim seviyesi cinsel tacizi şikayet edip etmeme ya da tacizciye tepkide bulunma konusunda etken değildir.

Taciz sonrası kadınların verimliliğinin düştüğü saptanmıştır.

Banka ortamında çoğunlukla amirlerin tacize yönelik yakışıksız davranş̧lara uygun bir ortam oluşturmadıkları, ancak kendilerine iletilen taciz olaylarında tacizciye karşı hiçbir işlem yapmadıkları da belirlenmiştir.

Bankalann cinsel tacizi önlemeye yönelik politikalarının olmadığı saptanmıştır. Hizmet içi eğitim programlarında cinsel taciz ve sonuçları ile ilgili bir eğitim söz konusu değildir. Kadınların cinsel tacizi şikayet edecekleri bir ortam yaratılmamış ve şikayet prosedürleri oluşturulmamıştır.

Cinsel taciz cinsiyet ayrımcllı̆ının bir uzantısıdır. Cinsel taciz kadının onurla çalışma hakkına karşı bir tehdittir. Yasal düzenlemeler ve uygulamalar dışında kadının insanca yaşama ve çalışma hakkına zarar verecek toplumdaki yanlış anlayışların değiştirilmesi, geleneklerin kırılması gerekmektedir. Işyerlerinde kadını öncelikle cinsel kimliği ile değil üretici kimliği ile algılamaları ve kabul etmeleri için, erkeklere karşı cinse sağlıklı bakış açısı eğitimle kazandırlabilir. Konunun çeşitli ortam ve düzeylerde gündeme gelmesi ve konuşulup tartışılması da geleneksel bakıs açılarını değiştirmek için önemli adımlardır.

Ayrıca örgütlerin cinsel tacizi önlemede çok büyük sorumlulukları vardır. Genellikle işyeri yöneticileri cinsel tacizin önemli bir problem olduğunun farkında değildirler. Yöneticilerin cinsel tacizin önemini kavraması, kurumda bu tarz davranışlara tavizkâr davranmaması gerekir. Çalışanlar hizmet-içi eğitim programlarıyla cinsel tacizin önemi ve etkileri konusunda eğitilmelidir.

Tacizle ilgili şikayet prosedürleri oluşturulması ve yöneticilerle çalışanlar arasında açk bir iletişimin sağlanması önemlidir. Örgütlerin eşit istihdam politikaları izlemesi, hem sayların önemli bir güç kaynağı oluşturması 
noktasından hem de kadınların cinsiyet ağırlıklı görüntülerinin silinmesi bakımından son derece önemlidir.

Kurumsal ve kişisel güç kaynakları cinsel taciz amacıyla kadınlara karşı kullanulabiliyorsa, örgütlerde gücün sadece erkeklerin elinde toplanmasın engelleyerek cinsiyete değil, liyakate göre insanları değerlendirebilmek tacizi büyük ölçüde engelleyebilir.

Cinsel taciz algılamalarında cinsiyetler arasında farklar olması nedeniyle; algısal setlerdeki farkları anlamak, farklı algıları örgütlerde geçerli kılmak, tacizi algılamada mağdurun arkadaşlanından destek sağlaması bakımından önemlidir.

Güvenli, huzursuzluklardan arındırılmış bir iş ortamı sunmak, çalışanların verimini yükselterek kurumların etkinliğini artırır. Gelecekteki araştırmaların cinsel tacizin ortaya çımasına neden olan koşullara ve örgütün sosyal gelişimine faydalı olacak eğitim tekniklerini belirlemeye odaklanmaları gerekmektedir.

\section{Kaynakça}

AKKUN, I., / KAVAK, Y. / SEMENOĞLU, N. (1996), Is ve Iş̧i Bulma Kunumu Işgücü Yetiştime ve Mesleki Rehabilitasyon Hizmetlerinin Kadın Istihdamına Katkısı Açısından Değerlendirilmesi Araştıması (Ankara: Yayınlanmamış Rapor).

BAKIRCI, K. (2000), Iş Hukuku Açısından /şyerinde Cinsel Taciz (Istanbul: Yasa Yayınları).

CLEVELAND, J.N. (1994). "Women and Sexual Harassment: Work and Well-Being in US Organizations," DAVIDSON, M.J. / BURKE, R.J. (Eds.) Women in Managament (London: Paul Chapment Publishing): $169-191$.

CLEVElAND, J.N. / KERST, M.E. (1993), "Sexual Harassment and Perceptions of Power: An Under-Artjculated Relationship," Joumal of Vocational Behaviour, 42: 49-67.

DAVIDSON, M.J. / EARNSHAW, J. (1990), "Policies, Practices and attitudes towards Sexual Harassment in U.K. Organizations," Personnel Review, 19:23-27.

DI TOMASO, N. (1989), "Sexuality in the Workplace: Discrimination and Harassment," HEAN, J. / SHEPPORT, D.L. / TANCRED.SHERIFF, P. / BURRELL. G. (Eds.). The Sexuality of Organization (Newbury Park, CA: Sage): $71-90$.

ELHAN, G.S., / METIN, P. / PERVZAT, L. (2000), Sağlık Sektöründe Kadun (Sağlık Sektöründe Kadınlara Yönelik Tulum ve Davranışlar, Cinsiyete Dayalı Aynmcilik) (Ankara: T.C Başbakanlık Kadının Statüsü ve Sorunlanı Genel Müdürlügü Yayını).

EYÖBOǦLU, D. / INCIR, G. N. / ILGAZ, A FIDAN, E. / INCE, Y. (2000). Bankacilik Sektöründen Cinsiyete Dayal Ayrimcilk (Calıșa Yaşamunda Cinsiyete Dayal Ayrumcilk: Bankacilik Sektöründe Omek Olay Incelemesi) (Ankara: T.C Başbakanlık Kadının Statüsũ ve Sorunları Genel Müdürlügü Yayıı).

FAIN, T.C. / ANDERTON, D.L. (1987), "Sexual Harassment: Organizational Context and Diffuse Status," Sex Roles, 17: 291-311.

FITZGERALD. LF. / SHULLMAN, S.L. / BAILY, N. / RICHARDS, M. / SWECKER, J. / GOLD, Y. / ORMAROD. M. / WATZMAN, L. (1988). "The Incidence and Dimensions of Sexuel Harassment in Academia and the Workplace," Joumal of Vocational Behaviour, 32:152-175. 
FTIZGERALD, L.F. / SHULLMAN, S.L (1993). "Sexual Harassment: A Research Analysis and Agenda for the 1990s," Joumal of Vocational Behaviour, 42: 5-27.

FTZGERALD, L.F. / WETTTMAN, L.M. (1990) "Men Who Harass: Speculation and Date," PALUDI, M.A. (Ed.), lvory Power: Sexual Harassment on Campus (New York: State University of New York. Press, Albary).

GERMI. G.M. (2000), Yönetimde Kadinlar (Enurum: Atatürk Úniversitesi IlBF Z.Fahri Fındıkołlu Araştırma Merkezi Yayını).

GUTEK, B.A. (1985). Sex and the Workplace (San Francisco, CA.: Jossey Bass).

GUTEK, B.A. (1989). "Sexuality in the Workplace: Key Issues in Social Reserch and Organizational Practice", HEARN, J. / SHAPPARD, D.L. / TANCREDSHERIFF, P. / BURREL, G. (Eds.). The Sexuality of Organization (London: Sage Publications).

GUTEK, B.A. / DUNWOODY, V. (1987), "Understanding Sex in the Workplace," STONBERG, A.H. / LARWOOD, L. / GUTEK, B.A. (Eds.) Women and Work: An Annual Review (Beverly Hills, CA.: Sage): $249 \cdot 270$.

GUTEK, B.A. / COHEN, A.G. / KONRAD. A.M. (1990). "Predicting Social-Sexual Behaviour at Work: A Contact Hypothesis," Academy of Management Jumal, 33: 560-577.

GUTEK, B.A. (1993), Personnel Communication Society for Industrial and Organizational Psychology (San Francisco, CA).

KIPNIS, D. (1990), Technology and Power (New York/Berlin: Spriger-Verlag).

KORAY, M. / DEMIRBILEK, S. / DEMIRBILEK, T. (1999), Gida Işkolunda Calışan Kadinlarn Koşullan ve Geleceği (Ankara: T.C. Başbakanlık Kadının Statüsü ve Sorunları Genel Müdürlüğũ Yayın).

LAFONTAINE, E. / TREDEAU, L. (1986), "The Frequency, Sources, and Correlates of Sexual Harassment among Women in Traditional Male Occupations," Sex Roles: 433-442.

LARWOOD, L. / GUTEK, B.A. (1984), "Women at Work in the USA," DAVIDSON, M.J. /COOPER, C.L. (Eds.), Working Women: An Intemational Survey: 237.267.

LOY, P.H. / STEWART. L.P. (1984). "The Extend and Effects of Sexual Harrasment on Working Women," Sociological Focus, Cilt: 1 7: $31-43$.

MAC KINNON, K. (1979), Sexual Harassment of Working Women (New Haven: Yale University Press).

MORRISON, A.M. / VON GLINOV, M.A. (1990), "Women and Minorities in Management," American Psychologist, 45: 200-208.

MORRISON, A.M. / WHITE, R.P. / VAN VELSOR, E. (1987), Breaking The Glass Ceiling (Reading, A.M: Addison-Wesley).

RENICK, J. (1980), "Sexual Harassment at Work: Why It Happens, What to Do About it?, Personel Joumal. August: 658.682 .

RYAN, J. / KENIG, S. (1991), "Risk And Ideology in Sexual Harassment," Sociological Inquary, 61: 231 -241.

STEPHENSON, H. / WATKINS, J. / WALLACE, J. / SCHWERIN, M.T. / VAUX, A. (1989), "Survey of Sexual Harassment at Southem Illinois University." Techincal Report, Applied Research Consultants, Departmant of Psychology (Corbondale: Southem Illinios University).

TBB (2001), Türkiye Bankalar Birliğl, www.tbb.org.tr

Tempo Araştırma (1996). Işyerinde Cinsiyete Dayalı Aynmcılık ve lşverenterin Kadın Calışanlara Karşı Tutumu: Büro ve Mağaza Çalışanlanna Derinlemesine Bir Bakış (Yayınlanmamış Rapor).

TŬBA (1993). Is Iş̧i Calışma Bülteni (Ankara: Türkiye Basın Ajansı). 
44. Ankara Üniversitesi SBF Dergisi • 56-3

U.S. Merit System Protection Board (1981), Sexual Harassment in the Federal Workplace: Is it a Problem? (Washington: United States Goverment Printing Offlce).

U.S.Merit System Protection Board (1995). Harassment in the Federal Workplace: Trends, Sexual Progress, Continuing Challenges (Washington: U.S. Government Printing Office). 
Ek 1: Tacize Uğrama ile Medeni Durum

\begin{tabular}{|l|c|c|}
\hline \multicolumn{1}{|c|}{ Taciz Olayı } & Evet; oldu & Hayır; olmadı \\
Medeni Durum & & 17 \\
\hline Bekar & 13 & 1 \\
Nişanlı & 1 & 31 \\
Evli & 15 & - \\
Dul & - & 49 \\
\hline Toplam & 29 & \multicolumn{2}{|c|}{$1,039(0,959)$} \\
\hline Ki-kare testi & \multicolumn{2}{|c|}{} \\
\hline
\end{tabular}

Ek 2: Tacize Uğrama ile Eğitim Seviyesi

\begin{tabular}{|l|c|c|}
\hline \multicolumn{1}{|c|}{ Taciz Olayı } & Evet; oldu & Hayır; olmadı \\
Eğitim Seviyesi & & - \\
\hline Ortaöğretim & - & 22 \\
Lise ve dengi & 8 & 24 \\
Yüksekokul/Üniversite & 21 & 1 \\
Lisansüstü & - & 47 \\
\hline Toplam & 29 & \multicolumn{2}{|c|}{$3,767(0,159)$} \\
\hline Ki-kare testi & \multicolumn{2}{|c|}{} \\
\hline
\end{tabular}

Ek 3: Ikamet Edilen Yerde Kalma Süresi ile Taciz Olayı

\begin{tabular}{|l|c|c|}
\hline Taciz Olayl & Evet; oldu & Hayr; olmad1 \\
\hline Erzurum'da ikamet edilen y1l & & 9 \\
0-5 yll & 3 & 5 \\
6-10 yll & 4 & 5 \\
11-15 yl & 2 & 30 \\
\hline 16 ve üzeri yll & 20 & 49 \\
\hline Toplam & 29 & \multicolumn{2}{|c|}{$1,358(0,715)$} \\
\hline Ki-kare testi & \multicolumn{2}{|c|}{29} \\
\hline
\end{tabular}


Ek 4: Çalışma Süresi ile Taciz Olayı

\begin{tabular}{|l|c|c|}
\hline \multicolumn{1}{|c|}{ Taciz Olayı } & Evet; oldu & Hayır; olmadı \\
Kurumda çalışılan yıl & & 18 \\
\hline 0-5 yıl & 17 & 3 \\
6-10 yıl & 3 & 12 \\
11-15 yıl & 3 & 16 \\
16 ve üzeri yıl & 6 & 49 \\
\hline Toplam & 29 & $(0 ; 159)$ \\
\hline Ki-kare testi & \multicolumn{2}{|c|}{$5,187 \quad(2)$} \\
\hline
\end{tabular}

Ek 5: Çalışanun Unvanı ile Taciz Olayı

\begin{tabular}{|l|c|c|}
\hline \multicolumn{1}{|c|}{ Taciz Olayı } & Evet; oldu & Hayır; olmadı \\
Unvan & 12 & 20 \\
\hline Memur & 9 & 21 \\
Şef & 1 & 2 \\
Müdür yardımcısı & - & 1 \\
Müdür & - & 1 \\
Bölge müdürü & 1 & 1 \\
Bölge müdür yardımcısı & 23 & 46 \\
\hline Toplam & \multicolumn{2}{|c|}{$1,650 \quad(0,895)$} \\
\hline Ki-kare testi & \multicolumn{2}{|c|}{} \\
\hline
\end{tabular}

Ek 6: Eğitim Seviyesi ile Kişinin Taciz Karşısındaki Tutum

\begin{tabular}{|l|c|c|c|c|c|}
\hline Tacize Karşı Tutum & $\begin{array}{c}\text { Sessiz } \\
\text { kalmak }\end{array}$ & $\begin{array}{c}\text { Tacizciye } \\
\text { tepkide } \\
\text { bulunmak }\end{array}$ & $\begin{array}{c}\text { Durumu } \\
\text { yakın } \\
\text { arkadaşlarla } \\
\text { paylaşmak }\end{array}$ & $\begin{array}{c}\text { Amiri } \\
\text { bilglendirmek }\end{array}$ & $\begin{array}{c}\text { Olay adli } \\
\text { mercilere } \\
\text { intikal } \\
\text { ettirmek }\end{array}$ \\
\hline Ortaöğretim & - & - & - & 1 & - \\
Lise ve dengi & 3 & 2 & 5 & - & - \\
Yüksekokul/Üniversite & 5 & 5 & 7 & - & - \\
Lisansüstü & - & 1 & - & 1 & - \\
\hline Toplam & 8 & 8 & 12 & - & - \\
\hline Ki-kare testi & & \multicolumn{7}{|c|}{$4,665(0,587)$} \\
\hline
\end{tabular}

